\title{
MENINGKATKAN KEMAMPUAN KOGNITIF ANAK MELALUI PEMBELAJARAN TEMATIK DENGAN METODE EKSPERIMEN BERCOCOK TANAM DI KELOMPOK B
}

\author{
${ }^{1}$ Kristina Wahyu C, ${ }^{2}$ Dita Debita, ${ }^{3}$ Rohmalina \\ ${ }^{1}$ IKIP Siliwangi, Jl. Terusan Jendral Sudirman, Cimahi \\ ${ }^{2}$ IKIP Siliwangi, Jl. Terusan Jendral Sudirman, Cimahi \\ ${ }^{3}$ IKIP Siliwangi, Jl. Terusan Jendral Sudirman, Cimahi \\ 1kristina.cahyaningsih@gmail.com, ${ }^{2}$ dita.debita21@gmail.com, ${ }^{3}$ rohmalina@,ikipsiliwangi.ac.id.
}

\begin{abstract}
Abstrack
The teacher's job in designing and implementing learning requires a variety of knowledge, skills, and perhaps not all teachers have the ability to cultivate, presenting a learning theme that can dig into all the potential of the child's own. The method used tends to be monotonous, so learning becomes boring for the child. Based on that, the basic reason for the problem is that through thematic learning with experimental method of planting can improve the cognitive ability of child group B?. The purpose of this research is to know the thematic learning activities with the methods of planting experiments performed in group B that can improve the cognitive ability of children. This study uses a qualitative approach with a descriptive method. The process of thematic learning is done adapted to the theme that is running, namely the theme of plants, on the implementation through Taha-the preparation stage of syllabus such as drafting RPPM and RPPH, activities divided into 3 phases: the core activities, activities End and reflection activities. Based on the results of thematic learning with suitable planting methods, it has an impact on improving the cognitive abilities of child group B. It can be seen from several indicators of cognitive assessment of children before and after planting methods indicates optimal development.
\end{abstract}

Keywords: cognitive ability, thematic learning, experimental methods, farming

\begin{abstract}
Abstrak
Tugas guru dalam merancang dan melaksanakan pembelajaran dibutuhkan pengetahuan, keterampilan yang bervariasi, mungkin belum semua guru memiliki kemampuan dalam mengolah, menyajikan tema pembelajaran yang dapat menggali semua potensi yang dimiliki anak. Metode yang digunakan cenderung monoton, sehingga pembelajaran menjadi membosankan bagi anak. Berdasarkan hal tersebut yang menjadi alasan mendasar rumusan masalah yaitu apakah melalui pembelajaran tematik dengan metode eksperimen bercocok tanam dapat meningkatkan kemampuan kognitif anak kelompok B?. Adapun tujuan dari penelitian ini adalah untuk mengetahui kegiatan pembelajaran tematik dengan metode eksperimen bercocok tanam yang dilakukan di kelompok B yang dapat meningkatkan kemampuan kognitif anak. Penelitian ini menggunakan pendekatan kualitatif dengan metode deskriptif. Proses pembelajaran tematik yang dilakukan disesuaikan dengan tema yang sedang berjalan, yaitu tema tanaman, pada pelaksanannya melalui taha -tahap penyusunan silabus seperti menyusun RPPM dan RPPH, kegiatan terbagi dalam 3 tahap : inti kegiatan, kegiatan akhir dan refleksi kegiatan. Berdasarkan hasil pembelajaran tematik dengan metode bercocok tanam sangat berdampak pada peningkatan kemampuan kognitif anak kelompok B. Hal tersebut dapat
\end{abstract}


dilihat dari beberapa indikator penilaian kognitif anak sebelum dan sesudah metode bercocok tanam menunjukan perkembangan yang optimal.

Kata kunci: Kemampuan kognitif, pembelajaran tematik, metode eksperimen, bercocok tanam

\section{PENDAHULUAN}

Pendidikan anak usia dini pada dasarnya meliputi seluruh upaya dan tindakan yang dilakukan oleh pendidik dan orang tua dalam proses perawatan, pengasuhan, serta pemberian pendidikan pada anak dengan menciptakan aura dan lingkungan dimana anak dapat mengeksplorasi pengalaman yang memberikan kesempatan kepadanya untuk mengetahui dan memahami pengalaman belajar yang diperolehnya melalui cara mengamati, meniru, dan bereksperimen, yang berlangsung berulang-ulang dan melibatkan seluruh potensi dan kecerdasan anak. (Mursid, 2015: 15).

Taman Kanak-kanak merupakan salah satu bentuk pendidikan anak usia dini pada jalur formal untuk rentang usia 4-6 tahun,keberadaanya mampu memberikan kontribusi dalam membantu anak mengembangkan seluruh aspek perkembangan yang dimilikinya (Isjoni, 2011: 55). Dalam mencapai tujuan perkembangan anak, diperlukan pembelajaran dengan metode pendekatan yang dapat meningkatkan seluruh aspek perkembangan.

Untuk mencapai tujuan dari semua aspek perkembangan anak, seorang pendidik harus mampu menciptakan suasana kegiatan pembelajaran yang menyenangkan dan berorientasi pada perkembangan anak, guru harus memiliki pengetahuan dan pemahaman tentang kurikulum TK serta perencanaan pembelajaran yang sesuai dengan aktivitas yang dikembangkan. Kurikulum Taman Kanak-kanak yang meliputi konsep pendidikan anak usia dini, fungsi, tujuan pendidikan TK, komponen-komponen yang terdapat dalam kurikulum TK, serta prinsip-prinsip pengembangan dan pelaksanaan kurikulum TK.

Agar dapat memperoleh hasil pembelajaran yang maksimal dan sesuai dengan tujuan pembelajaran serta aspek perkembangan anak yang meliputi perkembangan nilai agama dan moral, kognitif, bahasa, sosial emosional, fisik motorik, dan seni, guru diharapkan dapat mencari, menggunakan strategi dan metode yang tepat dalam upaya mengembangkan pengetahuan, ketrampilan, kreativitas anak, salah satunya dengan memanfaatkan alam sekitar, yang terkadang luput dari perhatian guru. Pemanfaatan alam sekitar tersebut dapat dilakukan salah satunya dengan metode eksperimen.

Eksperimen atau percobaan adalah suatu kegiatan yang di dalamnya dilakukan cobaan dengan cara mengamati proses dan hasil dari percobaan tersebut.(Rohmalina, dkk, 2019 hlm 19)

Melalui metode eksperimen diharapkan anak mampu mengembangkan seluruh aspek perkembangannya, terutama perkembangan kognitifnya, Perkembangan kognitif merupakan hal sangat penting bagi anak usia dini khususnya anak kelompok bermain (KB) dan Taman Kanak- kanak (TK). Perkembangan kognitif pada anak bertujuan untuk mengembangkan kemampuan berpikir secara kritis, 
memberi alasan, memecahkan masalah, dan menghubungkan sebab akibat.

Dengan menggunakan metode eksperimen melalui kegiatan bercocok tanam tersebut pembelajaran menjadi lebih menyenangkan serta dapat meningkatkan kemampuan kognitif anak, metode tersebut masih banyak yang belum dilakukan oleh guru dikarenakan masih minimnya pengetahuan,ketrampilan serta kemauan dari guru tersebut. Berdasarkan uraian latar belakang diatas, peneliti ini mengangkat judul Meningkatkan Kemampuan Kognitif Anak Melalui Pembelajaran Tematik Dengan Metode Eksperimen Bercocok Tanam di Kelompok B, TK KARTIKA XIX- 43.

Menurut Hatimah (2014: 6) Pembelajaran adalah interaksi antara peserta belajar dengan lingkungan belajar yang dikelola oleh pendidik dalam rangka pencapaian tujuan pembelajaran. Interaksi yang terjadi dalam kegiatan pembelajaran dapat terjadi satu arah (one way communication), dua arah (two way communication), dan banyak arah ( multi way communication).

Hakekat pembelajaran bagi anak usia dini termasuk TK di dalamnya memiliki kekhasan tersendiri. Kegiatan pembelajaran di TK mengutamakan bermain sambil belajar dan belajar sambil bermain, dalam hal ini pembelajaran tematik dipilih sebagai suatu metode pendekatan pembelajaran. Menurut Suyanto, (2013: 253), pembelajaran tematik merupakan pembelajaran terpadu yang menggunakan tema sebagai pemersatu dan pengikat materi dari beberapa mata pelajaran secara terintegrasi.

Dalam pembelajaran tematik diperlukan suatu metode yang digunakan sebagai cara atau tekhnik dalam melakukan proses kegiatan pembelajaran tersebut. Metode dalam pembelajaran tidak hanya berfungsi sebagai cara untuk menyampaikan materi saja, sebab pendidik dalam kegiatan pembelajaran mempunyai tugas untuk mengelola kegiatan pembelajaran sehingga peserta didik dapat belajar untuk mecapai tujuan belajar secara cepat. (Hatimah, 2014: 25).

Metode pembelajaran yang dipakai oleh guru salah satunya yaitu metode eksperimen, dalam penelitian ini dengan kegiatan bercocok tanam. Menurut Roestiyah (2012: 80) mengungkapkan metode eksperimen adalah salah satu cara mengajar, dimana siswa melakukan suatu percobaan tentang sesuatu hal, mengamati prosesnya serta menuliskan hasil percobaannya, kemudian hasil pengamatan itu disampaikan ke kelas dan dievaluasi oleh guru.

Perkembangan dan pertumbuhan merupakan sebuah perubahan. Perubahanperubahan yang terjadi merupakan suatu proses dan prosesnya tidak sama, ada yang cepat, ada yang sedang, dan ada yang lambat. Dari kategori prosesnya tersebut, dalam memberikan pelayanan pendidikan seorang guru harus menyesuaikan dengan keadaan peserta didik. (Sutirna, 2013: 56).

Kemampuan berpikir (kognitif), dalam perkembanganya kemapuan berpikir dimaksudkan agar anak dapat mengolah apa yang diperoleh dari belajarnya, mampu memecahkan masalah dalam keseharianya dan dapat mengembangkan kemampuan matematikanya (Isjoni, 2011: 64). Tujuan pengembangan daya pikir (kognitif) secara rinci adalah sebagai berikut :

a. Mengembangkan kemampuan berpikir logis dan pengetahuan akan ruang dan waktu. 
b. Anak mampu mengembangkan pengetahuan yang sudah diketahui dengan pengetahuan baru yang diperolehnya.

c. Mengembangkan kemampuan memahami sesuatu dengan cara melihat bermacam-macam hubungan antara satu objek dengan objek lain berdasarkan perbedaan dan persamaan.

d. Mengembangkan imajinasi melalui bermacam-macam kegiatan.

e. Memberi kesempatan untuk mengolah lingkungan dan membangun dunianya secara aktif.

f. Agar anak dapat menghargai dan mencintai isi alam sebagai ciptaan Tuhan.

Salah satu metode eksperimen dalam pembelajaran adalah kegiatan bercocok tanam. Pengertian dari bercocok tanam adalah kegiatan menanam tanaman tumbuhan pada media tanah atau non tanah seperti sekam, kerikil dan lain-lain. Wadah atau tempat yang digunakan bermacam-macam bisa langsung pada tanah, pot, drum, dan tempat bekas lain (Yandiyanto, 2003: 14)

\section{METODE PENELITIAN}

Metode dalam penelitian ini peneliti menggunakan pendekatan kualitatif dengan metode deskriptif, yaitu melakukan penelitian dengan tujuan ingin menggambarkan masalah dan melakukan analisis terhadap masalah, sehingga dapat digambarkan pemecahan masalahnya secara tepat. Dalam hal tersebut menggambarkan kegiatan eksperimen bercocok tanam dalam upaya meningkatkan kemampuan kognitif anak.

\section{HASIL DAN PEMBAHASAN}

\section{HASIL}

Penelitian diawali dengan melakukan observasi sebelum kegiatan eksperimen bercocok tanam untuk meningkatkan kemampuan kognitif anak. Hal ini dilakukan untuk mengetahui kondisi awal siswa TK Kartika XIX - 43 sebelum mendapat pembelajaran tematik dan pelaksanaannya. Kemudian pelaksanaan dilakukan selama $3 \quad \mathrm{x}$ pertemuan pembelajaran $(1 \quad \mathrm{x}$ dalam seminggu). Pedoman pelaksanaan yang digunakan terdiri dari beberapa pertanyaan observasi yang telah diuji kebenaranya. Adapun hasil pelaksanaanya dapat dilihat pada pokok bahasan hasil penelitian.

Pembelajaran dilaksanakan selama $3 \mathrm{x}$ pertemuan $(1 \mathrm{x}$ pertemuan dalam 1 minggu ) dengan durasi 60 menit dalam pertemuannya. Berikut gambaran pelaksanaan pembelajaran : Anak dikondisikan 1). Diberikan pengarahan tentang kegiatan yang akan dilakukan yaitu bercocok tanam. 2). Diperkenalkan alat, bahan yang sebelumnya telah dipersiapkan oleh guru untuk kegiatan bercocok tanam. 3). Di beritahukan aturan sebelum dan sesudah kegiatan dimulai. Lamanya waktu yang digunakan dalam proses belajar adalah hari Rabu atau Kamis dimulai dari pukul $8.30-10.00$ WIB. Dengan alokasi waktu pembelajaran TK Kartika yaitu kegiatan pembukaan selama 30 menit, kegiatan inti selama 60 menit, diakhiri dengan penutupan selama 30 menit.

Pada dasarnya para guru telah melaksanakan langkah - langkah proses kegiatan pembelajaran tersebut sesuai dengan standar pendidikan yang tercantum dalam Permendikbud Nomor 146 tahun 
2014 tentang kurikulum 2013. Karakteristik kurikulum 2013 yaitu:

1. Mengoptimalkan perkembangan anak yang meliputi aspek nilai agama dan moral, fisik motorik, bahasa, kognitif, sosial emosional, dan seni yang tercermin dalam keseimbangan kompetesi sikap, pengetahuan, dan keterampilan.

2. Menggunakan pembelajaran tematik dengan pendekatan saintifik dalam memberikan rangsangan pendidikan.

3. Menggunakan penilaian autentik dalam memantau perkembangan anak dan,

4. Memberdayakan peran orang tua dalam proses pembelajaran.

Penilain dalam penelitian ini dilakukan dengan menggunakan pedoman observasi dalam bentuk checklist, kriteria penilaian yang digunakan dalam pembelajaran tematik metode eksperimen bercocok tanam ialah : Belum berkembang (BB), Mulai berkembang (MB), Berkembang sesuai harapan (BSH), dan Berkembang sangat baik (BSB).

\section{PEMBAHASAN}

Berdasarkan observasi awal sebelum kegiatan eksperimen bercocok tanam dilakukan, di peroleh data melalui hasil wawancara dengan guru serta lembar observasi dengan indikator -indikator sebagai berikut :

1. Mengembangkan kemampuan berpikir logis dan pengetahuan akan ruang dan waktu. Sebagian dari anak masih belum dapat mengetahui ataupun membedakan ukuran benda, besarkecil, panjang- pendek, serta mengelompokan benda berdasarkan warna, dalam mengenal tanaman, belum berkembang (BB).

2. Anak mampu mengembangkan pengetahuan yang sudah diketahui dengan pengetahuan baru yang diperolehnya, dalam hal mengetahui asal mula tanaman, belum berkembang (BB).

3. Mengembangkan kemampuan memahami sesuatu dengan cara melihat bermacam- macam hubungan antara satu objek dengan objek lain berdasarkan perbedaan dan persamaan, dalam hal tanaman menbutuhkan air untuk dapat hidup seperti manusia membutuhkan makanan dan minum untuk bertahan hidup, mulai berkembang (MB).

4. Mengembangkan imajinasi melalui bermacam- macam kegiatan. Memberi kesempatan untuk mengolah lingkungan dan membangun dunianya secara aktif, dalam hal menanam berbagai jenis tanaman melalui berbagai media, belum berkembang (BB)

5. Anak dapat menghargai dan mencintai isi alam sebagai ciptaan Tuhan, dalam hal memelihara tanaman seperti merawat tanaman dengan menyiram setiap hari, mulai berkembang (MB).

Hasil observasi setelah dilakukan pembelajaran tematik dengan metode eksperimen bercocok tanam, kemampuan kognitif anak di TK Kartika XIX-43 mengalami peningkatan yang signifikan, seperti pada saat guru memberikan teknik pembelajaran pada anak. Anak - anak terlihat lebih aktif dan sangat antusias dalam mengikuti kegiatan bercocok tanam. Disamping itu anak telah menunjukan sikap - sikap yang positif, seperti melakukan kegiatan - kegiatan sesuai dengan indikator perkembangan kognitif.

Dampak dari penggunaan bercocok tanam ini terhadap peningkatan kemampuan kognitif anak sangat 
signifikan, hal tersebut berdasarkan penilaian indikator- indikator di bawah ini:

1. Mengembangkan kemampuan berpikir logis dan pengetahuan akan ruang dan waktu, berkembang sesuai harapan (BSH).

2. Anak mampu mengembangkan pengetahuan yang sudah diketahui dengan pengetahuan baru yang diperolehnya, berkembang sesuai harapan $(\mathrm{BSH})$.

3. Mengembangkan kemampuan memahami sesuatu dengan cara melihat bermacam-macam hubungan antara satu objek dengan objek lain berdasarkan perbedaan dan persamaan, berkembang sangat baik (BSH).

4. Mengembangkan imajinasi melalui bermacam-macam kegiatan. Memberi kesempatan untuk mengolah lingkungan dan membangun dunianya secara aktif, dalam hal menanam berbagai jenis tanaman melalui berbagai media. (MB)

5. Anak dapat menghargai dan mencintai isi alam sebagai ciptaan Tuhan, dalam hal memelihara tanaman seperti merawat tanaman dengan menyiram setiap hari (BSB).

Berdasarkan hasil pembahasan yang telah diuraikan, kegiatan pembelajaran tematik dengan metode bercocok tanam sangat berdampak pada peningkatan kemampuan kognitif anak di TK Kartika XIX - 43. Hasil observasi peningkatan kemampuan kognitif anak sebelum dan sesudah metode bercocok tanam menunjukan perkembangan yang optimal.

\section{KESIMPULAN}

Berdasarkan hasil penelitian dan pembahasan, dapat disimpulkan beberapa hal mengenai pembelajaran tematik dengan metode bercocok tanam untuk meningkatkan kemampuan kognitif anak di TK Kartika XIX - 43 Brigif, maka dapat disimpulkan dari pertanyaan penelitian sebagai berikut :

1. Proses pembelajaran tematik yang dilakukan di TK Kartika XIX - 43 disesuaikan dengan tema yang sedang berjalan, yaitu tema tanaman, pada pelaksanannya melalui tahap - tahap penyusunan silabus seperti menyusun RPPM dan RPPH, Kegiatan terbagi dalam 3 tahap : inti kegiatan, kegiatan akhir dan refleksi kegiatan.

2. Penggunaan metode bercocok tanam merupakan salah satu metode yang digunakan di TK Kartika XIX - 43 selain metode lainya dalam proses pembelajaran, penyampaian materi. Kegiatan bercocok tanam dilakukan dalam upaya peningkatan kemampuan kognitif anak.

3. Hasil dari pembelajaran tematik dengan metode bercocok tanam sangat berdampak pada peningkatan kemampuan kogtitif anak di TK Kartika XIX - 43 Brigif. Hal tersebut dapat dilihat dari beberapa indikator penilaian kognitif anak sebelum dan sesudah metode bercocok tanam menunjukan perkembangan yang optimal.

Pembelajaran tematik dengan metode bercocok tanam yang dilaksanakan di TK Kartika XIX -43 merupakan salah satu cara atau strategi dalam proses pembelajaran, dimana dalam proses penyampaian materi disesuaikan dengan minat, kebutuhan anak sehingga dapat tercapai aspek-aspek perkembangan anak. Dalam penelitian ini aspek yang dinilai adalah aspek perkembangan kognitif. 


\section{DAFTAR PUSTAKA}

Hatimah, I. (2014). Metode Pembelajaran. Bandung: RIZQI PRESS

Isjoni, (2011). Model pembelajaran anak usia dini. Bandung : Alfabeta

Mursid, (2015). Belajar dan Pembelajaran. Bandung : PT REMAJA ROSDAKARYA

Roestiyah, (2012). Strategi Belajar Mengajar. Jakarta : Rineka Cipta

Rohmalina. dkk. (2019) "Pengembangan Pengetahuan Sains Anak Usia DIni Melalui Metode Eksperimen di PAUD Wijaya Kusumah" Vol.2 No.1 | Januari 2019. (2019). Jurnal ceria. 2(1), 21-22.

Suyanto, (2013). Menjadi Guru Profesional. Jakarta : Erlangga

Sutirna,H. (2013). Perkembangan \& Pertumbuhan Peserta Didik. Yogyakarta: CV.ANDI OFFSET 